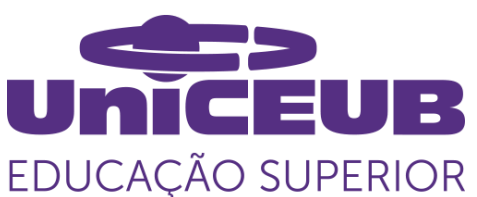

Centro Universitário de Brasília - UniCEUB

Faculdade de Ciências Jurídicas e Sociais - FAJS

Curso de Bacharelado em Direito

WALTER ALMEIDA BARBOZA

IMUNIDADES TRIBUTÁRIAS DOS TEMPLOS DE QUALQUER CULTO 
WALTER ALMEIDA BARBOZA

\section{IMUNIDADES TRIBUTÁRIAS DOS TEMPLOS DE QUALQUER CULTO}

Artigo científico apresentado como requisito parcial para obtenção do título de Bacharel em Direito pela Faculdade de Ciências Jurídicas e Sociais - FAJS do Centro Universitário de Brasília (UniCEUB).

Orientador: Prof. Dr. Cleucio Santos Nunes. 


\section{IMUNIDADES TRIBUTÁRIAS DOS TEMPLOS DE QUALQUER CULTO}

Artigo científico apresentado como requisito parcial para obtenção do título de Bacharel em Direito pela Faculdade de Ciências Jurídicas e Sociais - FAJS do Centro Universitário de Brasília (UniCEUB).

Orientador: Prof. Dr. Cleucio Santos Nunes.

BRASÍLIA-DF, 02 DE OUTUBRO 2020

BANCA AVALIADORA

Professor Dr. Cleucio Santos Nunes

Orientador

Professor(a) Avaliador(a) 


\title{
IMUNIDADES TRIBUTÁRIAS DOS TEMPLOS DE QUALQUER CULTO
}

\author{
Walter Almeida Barboza
}

\section{RESUMO}

O artigo tem por objetivo analisar o conceito, aplicação e controvérsias da imunidade tributária dos templos de qualquer culto, através da linha de pesquisa dogmática instrumental sob o ponto de vista da Constituição Brasileira de 1988, de parte da doutrina nacional e da jurisprudência do STF. Analisa também o histórico e evolução da imunidade tributária dos templos de qualquer culto atribuída pelas constituições brasileiras. Faz distinção entre imunidade, isenção e não incidência de tributos. Analisa diferentes conceitos e opiniões sobre o que são templos de qualquer culto segundo parte da doutrina. Analisa até que ponto a jurisprudência do STJ e do STF têm contribuído para verificar se há confusão entre patrimônio, renda e serviços das instituições religiosas e de seus administradores. Analisa também até que ponto a fé se transformou em um negócio. Aborda se é necessário ou não que os templos de qualquer culto cumpram requisitos constitucionais e infraconstitucionais perante a administração pública para pleitearem os benefícios fiscais da imunidade tributária. Verifica se a legislação atual é adequada para enfrentar o tema e se há projetos de lei em trâmite no Congresso Nacional Brasileiro com a intenção de extinguir, manter ou ampliar as imunidades para os templos de qualquer culto. $\mathrm{O}$ texto conclui que imunidades de templos de qualquer culto ainda é assunto controverso na doutrina nacional e nas jurisprudências do Superior Tribunal de Justiça - STJ e do Supremo Tribunal Federal - STF.

Palavras-chave: Imunidade Tributária. Templos de Qualquer Culto. Instituições religiosas. Limitações ao poder de tributar. 


\begin{abstract}
The purpose of this article is to analyze the concept, application and controversies of the tax immunity for temples of any cult, through the line of instrumental dogmatic research under thepointofviewof the Brazilian Constitution of 1988. Also, this article analyzes the history and evolution of the tax immunity of the temples of any cult attributed by the Brazilian constitutions, distinguishing between immunity, exemption and non-incidence of taxes, bringing different concepts and opinions about any cult's temples are, according to the doctrine. The article informs to the reader the extent of the jurisprudence of the Superior Court of Justice (STJ) and the Supreme Federal Court (STF), and the contribution to verify whether has confusion between heritage, income and religious institutions and their administrators services. It also evaluates the extent from where the faith became a business. The article addresses whether it is necessary for temples of any cult to comply with constitutional and requirements before the public administration to claim the tax benefits of tax immunity. The article verifies if the current legislation is adequate to face the theme and if there are law projects in process in the Brazilian National Congress with the intention of extinguishing, maintaining or expanding the immunities for the temples of any cult. The article concludes that immunities from any cult's temple are still a controversial subject in national doctrine and inthe jurisprudence of the STJ and the STF.
\end{abstract}

\title{
Keywords
}

Tributary Immunity. Any Cult's Temple. Religious Institutions. Tax process limitations. 


\section{INTRODUÇÃO}

A imunidade tributária sobre templos de qualquer culto já era presente no ordenamento jurídico brasileiro, mesmo que de forma velada, na Constituição da República de 1891, ao vedar aos Estados e à União de estabelecer, subvencionar ou embaraçar o exercício de cultos religiosos. Assim, surgiu essa espécie de imunidade tributária no Brasil que desde o período republicano até a Constituição Federal de 1937 foi regulada por normas infraconstitucionais, sendo que somente depois da Constituição Federal de 1946, promulgada após a queda do Estado Novo em 1945, passou a ter previsão constitucional expressa.

Atualmente a imunidade tributária dos templos de qualquer culto está prevista no Artigo 150, VI, “b”, da Constituição da República Federativa do Brasil, promulgada em 1988, que se traduziu em uma espécie de "limitação ao poder de tributar". Tal limitação não permite, em qualquer hipótese, que os entes políticos estabeleçam possibilidades de incidência de impostos sobre o patrimônio, renda e serviços dos templos de qualquer culto.

Dada sua relevância no contexto científico, acadêmico, social e político trataremos de apresentar nesse artigo, já na primeira parte, alguns conceitos doutrinários das imunidades tributárias, em especial a imunidade dos templos de qualquer culto, bem como abordaremos porque essa espécie de imunidade está contemplada na Constituição Federal. Também abordaremos, de forma sucinta, seu contexto histórico constitucional e as diferenças entre os conceitos de imunidade, isenção e não incidência de tributos do ponto de vista de parte da doutrina.

Num segundo momento, faremos uma revisão bibliográfica com base na doutrina e veremos como a jurisprudência dos tribunais superiores e as próprias instituições religiosas enfrentam o tema imunidade. Quais são os principais gargalos encontrados pelos envolvidos no tema das imunidades dos templos de qualquer culto. Nesse momento abordaremos também, de forma sucinta, o fato de que é notório o aumento da capacidade contributiva das instituições religiosas. Veremos até que ponto a fé se transformou em um negócio e qual o posicionamento dos tribunais superiores sobre possíveis confusões patrimoniais entre o que pertence à instituição religiosa e o que é de caráter privado de seus administradores. Veremos também a quem cabe provar que o patrimônio, renda ou serviço prestado pela instituição religiosa é ou não imune a impostos.

A terceira parte fará um arrazoado geral dos temas tratados na primeira e segunda partes desse artigo, em especial, veremos o que há de aceitável na atual legislação tributária 
sobre imunidades de templos de qualquer culto, se há oportunidades a serem ultrapassadas, se é possível a criação de uma lei federal e o que é necessário para pacificar o tema. Ainda deixaremos claro que o presente artigo não tem a mínima pretensão de esgotar o assunto e que sugerimos que novas pesquisas científicas devem continuar explorando o tema com o intuito de lançarem novas luzes sobre uma matéria que exige profundas reflexões.

\section{IMUNIDADE TRIBUTÁRIA}

\subsection{Conceito}

A imunidade tributária, está prevista na Constituição Federal de 1988, ${ }^{1}$ no art. 150, VI. Podemos entender a imunidade tributária como limitação constitucional ao poder de tributar. Há quem diga que se trata de uma regra excludente do poder de tributar. Também há entendimento de que as imunidades tributárias se respaldam em normas jurídicas de âmbito constitucional que obrigam ao legislador infraconstitucional uma espécie de proibição quanto à imposição de normas de conduta que compõem determinadas hipóteses de incidência.

As imunidades tributárias alcançam tão somente impostos. São consideradas cláusulas pétreas, nas palavras de Roque Antonio Carraza, não podem ser neutralizadas, nem pela lei, nem, muito menos, por quem a aplica de ofício ou contenciosamente. Por essa razão mostramse improsperáveis quaisquer linhas argumentativas ou atos normativos infraconstitucionais que tenham em mira reverter; ainda que de modo parcial, as vantagens que as imunidades tributárias trazem aos contribuintes. ${ }^{2}$

Assim, existem diversos conceitos sobre imunidade tributária na doutrina, senão vejamos:

Gilmar Mendes explica, que tradicionalmente, as imunidades têm sido compreendidas, ao lado dos princípios, como espécies de "limitações ao poder de tributar". A diferença é que enquanto estes disciplinam a forma de exercício da competência tributária, aquelas estabelecem hipóteses em que a competência não pode ser exercida de forma alguma.

1 BRASIL. [Constituição (1988)]. Constituição da República Federativa do Brasil. Disponível em: http://www.planalto.gov.br/ccivil_03/Constituicao/Constituicao.htm. Acesso em: 25 set. 2020.

2 CARRAZZA, Roque Antonio. Imunidades Tributárias dos templos e instituições religiosas. São Paulo: Noeses, 2015. p.20. 
As imunidades estabeleceriam verdadeiros limites ou proibições ao exercício do poder de tributar. Em certo sentido, é possível reconhecer nas imunidades formas de demarcar a competência tributária, isto é, diretrizes que compõem o próprio limite daquilo que é demarcado. A competência já nasce delimitada. ${ }^{3}$

Já no entendimento de José Hable a imunidade tributária é um tema previsto na Carta Magna de 1988, no Título VI, que trata das limitações ao poder de tributar. Desse modo sendo uma exclusão ao poder de tributar, a imunidade tributária é um privilégio constitucional, com a impossibilidade da incidência tributária, ou seja, há a não incidência, por não existir disposição legal que preveja a ocorrência do fato gerador do tributo. ${ }^{4}$

De outra forma Ricardo Lobo Torres tem o posicionamento de que as imunidades são vedações ao exercício do poder tributário que, tendo fundamento nos direitos de liberdade, não podem ser revogadas nem modificadas. A imunidade é intributabilidade, impossibilidade de o Estado criar tributos sobre o exercício dos direitos de liberdade, incompetência absoluta para decretar impostos sobre bens ou coisas indispensáveis à manifestação da liberdade, não incidência ditada pelos direitos humanos e absolutos anteriores ao pacto constitucional. ${ }^{5}$

Por outro lado Regina Helena Costa critica o tema e expõe que o entendimento da imunidade tributária como uma limitação ao poder constitucional de tributar, pode se verificar como uma afirmação vaga, ao colocar-se o instituto da imunidade ao lado de outras categorias jurídicas que com elas não se confundem. Restaria vago o conceito de imunidade tão somente como uma limitação ao poder constitucional de tributar posto que nessa categoria se enquadram os princípios, mas não deixa de se enquadrar no referido conceito. ${ }^{6}$

Regina Helena Costa manifesta-se contrária sobre o entendimento de que a imunidade tributária ocorre como hipótese de não incidência qualificada pela constituição, expressa justamente o oposto, ou seja, "essa incidência não ocorre no plano constitucional.",

3 MENDES, Gilmar Ferreira; BRANCO, Paulo Gustavo Gonet. Curso de Direito Constitucional 6. ed. São Paulo: Saraiva, 2011. p. 1482.

4 HABLE, José. A imunidade tributária: os requisitos infraconstitucionais para o seu reconhecimento nas Instituições de Educação e de Assistência Social. In: PAES, José Eduardo Sabo; MAGALHÃES, Juliana Aparecida. (org.) Terceiro Setor e Tributação. São Paulo: Elevação, v. 8, 2016, p. 256, 259.

5 TORRES, Ricardo Lobo. Tratado de Direito Constitucional Financeiro e Tributário: Valores e princípios constitucionais tributários. Rio de Janeiro: Renovar, 2005. p. 308.

6 COSTA, Regina Helena. Imunidades Tributárias: Teoria e Análise da Jurisprudência do STF. São Paulo: Malheiros, 2001, p. 38.

7 Ibidem. p. 40. 
Sobre o ponto de vista de que a imunidade é tratada como uma exclusão ou supressão da competência tributária, Regina Helena Costa entende que estar-se ia transmitindo uma ideia de que a competência fora originalmente outorgada e, posteriormente afastada. Ocorre que a Competência Tributária já nasce limitada, as normas de imunidade não incidem em um momento posterior, mas são contemporâneas, não havendo que se falar em exclusão ou supressão de norma de competência. ${ }^{8}$

Posicionamento similar ao de Regina Helena Costa é o de Robson Maia Lins, com os quais concordamos, uma vez que esses autores entendem o conceito de imunidade como norma constitucional que estabelece proibições ao legislador infraconstitucional quanto a possibilidade de emissão de normas jurídicas tributárias em face de determinadas hipóteses de incidência. ${ }^{9}$

Assim, entendemos que não faria sentido falar em supressão ou exclusão pois esses termos nos dariam a ideia de que a norma imunizante subtraiu a competência do ente político tributante. Dessa forma, entendemos que não seria possível suprimir ou excluir uma competência que não foi inserida no ordenamento jurídico.

\subsection{Imunidade tributária dos templos de qualquer Culto}

A Constituição Federal de 1988 resolveu proteger a fé, o credo das pessoas. Percebese isso pelo teor do art. 19, I, CRFB que diz ser vedado à União, aos Estados, ao Distrito Federal e aos Municípios: I - estabelecer cultos religiosos ou igrejas, subvencioná-los, embaraçar-lhes o funcionamento ou manter com eles ou seus representantes relações de dependência ou aliança, ressalvada, na forma da lei, a colaboração de interesse público.

Dessa forma, se eventualmente houvesse tributação de impostos sobre os templos de qualquer culto poder-se-ia embaraçar essa possibilidade de culto.

Assim, a Constituição de 1988 no Título VI- Tributação e Orçamento - Capítulo I Do Sistema Tributário Nacional - Seção II - Das Limitações ao Poder de Tributar - no art. $150, \mathrm{VI}$, " $b$ " estabeleceu que sem prejuízo de outras garantias asseguradas ao contribuinte, é

8 COSTA, Regina Helena. Imunidades Tributárias: Teoria e Análise da Jurisprudência do STF. São Paulo: Malheiros, 2001, p. 44

9 LINS, Robson Maia. Curso de Direito Tributário Brasileiro. São Paulo: Noeses, 2019. p. 296. 
vedado à União, aos Estados e aos Municípios, instituir impostos sobre templos de qualquer culto. ${ }^{10}$

Entende-se por isso que não se trata de benesse do Estado e que essa imunidade não viola o Estado laico porque a "igreja" está ao lado do Estado e colabora com o interesse público. Considera-se que a fé persegue o bem comum. O Estado sendo laico, não diz o que a "igreja" tem que fazer. Dessa forma, a "igreja" se envolve nas atividades do Estado perseguindo o bem comum nas atividades de interesse público, mas o Estado não se envolve nas atribuições espirituais das "igrejas". ${ }^{11}$

Essa liberdade de religião encontra-se respaldada no Artigo $5^{\circ}$ da Constituição Federal, que estabelece que todos são iguais perante a lei, sem distinção de qualquer natureza, garantindo-se aos brasileiros e aos estrangeiros residentes no País a inviolabilidade do direito à vida, à liberdade, à igualdade, à segurança e à propriedade, nos termos seguintes: VI - é inviolável a liberdade de consciência e de crença, sendo assegurado o livre exercício dos cultos religiosos e garantida, na forma da lei, a proteção aos locais de culto e a suas liturgias; VII - é assegurada, nos termos da lei, a prestação de assistência religiosa nas entidades civis e militares de internação coletiva; VIII - ninguém será privado de direitos por motivo de crença religiosa ou de convicção filosófica ou política, salvo se as invocar para eximir-se de obrigação legal a todos imposta e recusar-se a cumprir prestação alternativa, fixada em lei. ${ }^{12}$

Percebe-se assim que as garantias fundamentais estabelecidas no texto constitucional garantem aos cidadãos amplo e irrestrito acesso à liberdade de religião.

Explica Thiago Rafael Vieira, que a Imunidade Tributária Religiosa prevista no artigo 150, inciso VI, alínea “ $b$ ” da Carta Magna, impede a relação de subserviência típica entre sujeito ativo (Estado) e sujeito passivo (Contribuinte) da relação jurídica tributária, onde há uma imposição estatal ao contribuinte para que adimpla a exação fiscal na espécie de imposto, sem qualquer vinculação ao Estado sobre a utilização desta verba em qualquer atividade. ${ }^{13}$

10 BRASIL. [Constituição (1988)]. Constituição da República Federativa do Brasil. Disponível em: http://www.planalto.gov.br/ccivil_03/Constituicao/Constituicao.htm. Acesso em: 25 set. 2020.

11 VIEIRA, Thiago Rafael; REGINA, Jean Marques. Direito religioso: Questões Práticas. Porto Alegre: Concórdia, 2019.

12 BRASIL. [Constituição (1988)]. Constituição da República Federativa do Brasil. Disponível em: http://www.planalto.gov.br/ccivil_03/Constituicao/Constituicao.htm. Acesso em: 25 set. 2020.

13 VIEIRA, op. cit. 
Nesse mesmo entendimento, Roque Antonio Carraza nos ensina que a Constituição Federal garantiu a todas as pessoas a liberdade de culto, isto é, conferiu-lhes o direito à ampla e irrestrita liberdade religiosa. Esta pode ser compreendida em três dimensões, individual, social e política, abrangendo, na esfera individual, o direito de ter as suas convicções religiosas; no âmbito social, o direito de expor as suas convicções; e dentro de uma esfera política o direito à objeção de consciência. Assim, a Constituição Federal protege o foro íntimo das pessoas, a liberdade de culto e o de não se subtrair de suas obrigações legais em nome de suas convicções religiosas. ${ }^{14}$

Tem-se que na opinião de Aliomar Baleeiro, ${ }^{15}$ que não é a falta de capacidade contributiva que é a ratio essendi ${ }^{16}$ da imunidade dos templos de qualquer culto, mas sim a proteção da liberdade religiosa da liberdade de crença.

Roque Antonio Carraza aborda o tema dizendo que facilmente se percebe, a ratio essendi dos dispositivos constitucionais garantidores da liberdade religiosa pois é ela que garante, a todas as pessoas, sua religiosidade e, mais do que isso, permite que a divulguem e manifestem livremente. Diz ainda que a Constituição lhes conferiu a titularidade ativa do direito à ampla e irrestrita liberdade religiosa. Dessa forma, qualquer medida, seja legislativa, seja administrativa, que sem razão plausível, anule ou tolha a liberdade de culto, padecerá de inconstitucionalidade. ${ }^{17}$

Nessas circunstâncias fica evidenciado que a Carta Constitucional desonera, expressamente, os templos de qualquer culto a pagarem impostos que incidam sobre seus patrimônios, rendas e serviços com a finalidade de não embaraçar e de não inviabilizar suas atividades religiosas.

Com a finalidade de balizar o alcance da imunidade tributária dos templos, a doutrina aponta três teorias que predominam nesse contexto:

I - Teoria Clássico - Restritiva: os defensores dessa teoria sustentam que com base na isonomia das religiões e pelo que entendem como culto, o conceito de templo estaria limitado, estritamente, ao local propriamente dito para a celebração do culto, não se estendendo aos

14 CARRAZZA, Roque Antonio. Curso de Direito Constitucional Tributário. 28. ed. São Paulo: Ed. Malheiros, 2012, p. 845.

15 BALEEIRO, Aliomar. Limitações constitucionais ao poder de tributar. 7. ed. Rio de Janeiro: Forense, 1998.

16 RATIO ESSENDI. Razão de ser. Lex Magister. 2020. Disponível em: http://www.lex.com.br/Dicionarios.aspx?pagina=209. Acesso em: 27 set. 2020.

17 CARRAZZA, Roque Antonio. Imunidades Tributárias dos templos e instituições religiosas. São Paulo: Noeses, 2015. p. 22 
demais imóveis de propriedade da entidade religiosa. São adeptos desse pensamento: Pontes de Miranda ${ }^{18}$ e Sacha Calmon Navarro Coêlho. ${ }^{19}$

II - Teoria Clássico - Liberal: defendem os adeptos dessa teoria que estão abarcados pela imunidade dos templos de qualquer culto todo o patrimônio da entidade religiosa, ou seja, tudo que contribui para a realização da cerimônia religiosa, como por exemplo: a casa pastoral, as dependências contíguas e o estacionamento, bem como veículos, desde que afetados a essas finalidades. Aliomar Baleeiro ${ }^{20}$ e Regina Helena Costa, ${ }^{21}$ são defensores dessa teoria que é predominante na doutrina.

III - Teoria Moderna: entendem os defensores dessa teoria que a imunidade se estende ao patrimônio à renda e aos serviços que estejam vinculados às finalidades essenciais do templo. Está relacionada ao fenômeno religioso da laicidade colaborativa. Entende o templo como entidade, assim ganha conotação de organização ou associação. A imunidade abarca tudo que contribui para a consecução da atividade fim da igreja, seja renda patrimônio e serviços.

Para melhor entendimento do sentido da palavra culto, recorremos a Aliomar Baleeiro, que entende culto como sendo a prática religiosa propriamente dita. Um edifício só é templo se o completam as instalações ou pertenças adequadas àquele fim, ou se utilizam efetivamente no culto ou prática religiosa. ${ }^{22}$

Ainda nesse sentido, Regina Helena $\operatorname{Costa}^{23}$ complementa que os templos não possuem patrimônio, renda ou serviços, mas sim a pessoa jurídica que os detém, ou seja, a entidade mencionada no art. $150, \S 4^{0}$ " da Constituição, a qual a autora intitula de "igreja".

\subsubsection{Requisitos formais de constituição da entidade religiosa}

As entidades religiosas previstas no art. 150 , VI, “ $b$ ” e parágrafo $4^{\circ}$ da Constituição federal, gozam de imunidade quanto aos impostos, rendas e serviços. Essa imunidade que

18 MIRANDA, Francisco Cavalcanti Pontes de. Tratado de Direito Privado. Parte Geral. Rio de Janeiro: Borsói, 1954.

19 COÊLHO, Sacha Calmon Navarro. Curso de direito tributário brasileiro. 10. ed. Rio de Janeiro: Forense, 2015, p. 303

20 BALEEIRO, Aliomar. Limitações constitucionais ao poder de tributar. Atualização de Misabel Abreu Machado Derzi. 7. ed. Rio de Janeiro: Forense, 2006. p. 311.

21 COSTA, Regina Helena. Imunidades Tributárias - Teoria e Análise da Jurisprudência do STF.São Paulo: Malheiros, 2001

22 BALEEIRO, op. cit., p. 312.

23 COSTA, Regina Helena. Imunidades Tributárias - Teoria e Análise da Jurisprudência do STF. São Paulo: Malheiros, 2001, p. 158. 
representa a extensão do direito fundamental à liberdade de consciência e de crença, consagrado no art. $5^{\circ}$, incisos, incisos VI, VII e VIII, da Constituição Federal, goza de eficácia plena e de aplicação imediata. ${ }^{24}$

Não obstante isso, o próprio texto constitucional traz em seu art. 146, II, que cabe à lei complementar regular as limitações constitucionais ao poder de tributar. Assim, o Código Tributário Nacional ${ }^{25}$ em seu art. 14 estabelece que:

art. 14. O disposto na alínea "c" do inciso IV do artigo $9^{\circ}$ é subordinado à observância dos seguintes requisitos pelas entidades nele referidas:

I - não distribuírem qualquer parcela de seu patrimônio ou de suas rendas, a qualquer título;

II - aplicarem integralmente, no País, os seus recursos na manutenção dos seus objetivos institucionais;

III - manterem escrituração de suas receitas e despesas em livros revestidos de formalidades capazes de assegurar sua exatidão.

Por isso, ficam as entidades religiosas submetidas ao cumprimento das obrigações impostas pelo CTN para que, atendidos esses requisitos indispensáveis, possam usufruir da imunidade tributária prevista no texto constitucional sobre seu patrimônio, renda e serviços.

E ainda nas palavras de Roque Antonio Carraza, à lei complementar é reservado, no caso, apenas, o propósito de explicitação, afastando incertezas quanto ao alcance de tais desonerações e, no caso do Código Tributário Nacional em seu art. 14, ele pois, é que dá plena execução ao disposto no art. 150, "c" da Constituição Federal. E explica que qualquer lei ordinária que venha a disciplinar o assunto terá, na melhor das hipóteses, caráter exclusivamente declaratório. Se repetir a Constituição e a lei complementar pertinente, será inócua; se as restringir, inconstitucional. ${ }^{26}$

\subsubsection{Requisitos para efetivação do direito à imunidade}

Conforme abordado no tópico anterior, as entidades religiosas precisam sujeitar-se aos comandos constitucionais do art. 150 , VI, “ $b$ ”, parágrafo $4^{\circ}$ da Constituição Federal, bem

24 CARRAZZA, Roque Antonio. Imunidades Tributárias dos templos e instituições religiosas. São Paulo: Noeses, 2015, p.15.

25 BRASIL. Código Tributário Nacional. Disponível em:

https://www2.senado.leg.br/bdsf/bitstream/handle/id/496301/000958177.pdf? sequence=1\&isAllowed=y. Acesso: 29 set. 2020.

26 CARRAZZA, Roque Antonio. Imunidades Tributárias dos templos e instituições religiosas. São Paulo: Noeses, 2015 p.168, 169. 
como ao que dispõe o art. 14 do Código Tributário Nacional, Lei 5.172/1966, para gozarem das vantagens da imunidade tributária dos templos de qualquer culto.

Ainda nesse sentido, para o reconhecimento administrativo da imunidade tributária, nos ensina José Hable, não basta determinada pessoa, física ou jurídica, constituir um galpão, nominar de igreja, escola ou entidade de assistência social e começar a receber e atender pessoas, e só por isso querer pleitear e exigir benefícios de toda ordem, em especial, o fiscal. Diz ainda que é necessário que a entidade cumpra determinados requisitos expressos em normas que regulam as referidas atividades. Ainda registra que a imunidade tributária, em regra, não é reconhecida automaticamente, de forma gratuita e aleatória, fazendo-se necessário, por vezes, que o interessado requeira perante a autoridade administrativa competente, que apreciará a situação objetivamente, mediante comprovação cabal de todas as condições constitucionais e infraconstitucionais exigidas, sendo que o patrimônio, a renda e os serviços devem estar relacionados com suas finalidades essenciais ( $\mathrm{CF} / 88$, art. 150, § $\left.4^{\circ}\right)$, para que seja ou reconhecida a imunidade tributária, por meio de ato administrativo. ${ }^{27}$

\subsection{Distinção doutrinária entre imunidade, isenção e não incidência de tributos}

Não é incomum haver dúvida sobre os conceitos de imunidade, isenção e não incidência tributária. Dessa forma nos ensinam sobre o tema, diferentes doutrinadores, cada um com sua opinião pessoal:

\subsubsection{Imunidade}

Ives Gandra da Silva Martins, leciona que as imunidades exteriorizam vedação absoluta ao poder de tributar traçado pela Constituição Federal e que dessa forma não há nascimento nem obrigação do crédito tributário, por determinação superior e que há um interesse nacional superior a retirar, do campo da tributação, pessoas, situações, fatos considerados de relevo. Isso porque a imunidade, nas hipóteses constitucionais, constitui o instrumento que o constituinte considerou fundamental para, de um lado, manter a democracia, a liberdade de expressão e a ação dos cidadãos e, por outro lado, atrair os

27 HABLE, José. Curso de processo administrativo fiscal: teoria e prática, com ênfase nas decisões dos Tribunais Administrativo de Recursos Fiscais. Rio de Janeiro: Lumen Juris, 2020. p. 272, 274. 
cidadãos a colaborarem com o Estado, nas suas atividades essenciais, em que, muitas vezes, o próprio Estado atua mal ou insuficientemente, como na educação, e na assistência social. ${ }^{28}$ Na concepção de Aliomar Baleeiro, define-se imunidade, por seus efeitos como limitações constitucionais ao poder de tributar que não se confunde com isenção pois essa se dá no plano infraconstitucional. É regra constitucional expressa (ou implicitamente necessária), que estabelece a não competência das pessoas políticas da federação para tributar outros fatos e situações de forma amplamente determinada, sendo, portanto, regra de exceção e de delimitação que atua, não de forma sucessiva no tempo, mas concomitantemente e que só pode ser regulada por lei complementar (art. 146, CF). ${ }^{29}$

Importante destacar a crítica de Sacha Calmon Navarro Coêlho, sobre o art. 195, $\S 7^{\circ}$, da Constituição Federal, ao trazer a expressão isenção, que na verdade é uma imunidade, vez que o comando, no plano constitucional, não é facultativo para o legislador federal, que não goza no particular da margem de discricionariedade própria das isenções, as quais poderia conceder ou denegar ao sabor exclusivo de seu julgamento de conveniência e oportunidade. ${ }^{30}$

\subsubsection{Isenção}

No tocante às isenções tributárias propõe José Souto Maior Borges que tanto na isenção quanto na imunidade, não há pagamento de tributos, com a diferença, entre as duas espécies, de que na isenção, o poder tributário foi exercido para declarar excluído da tributação determinado bem, enquanto que, na imunidade, há proibição de que o poder de tributar seja exercido. Faz menção ao fato de que a maioria da doutrina nacional explica a isenção tributária como a dispensa legal da obrigação de pagamento do tributo. Entende, portanto, que a norma jurídica de isenção é do tipo pré-excludente de juridicização vez que, sua incidência tem o efeito de negar entrada no mundo jurídico ao suporte fático. Da sua incidência não resulta fato jurídico, mas sim impede que um fato jurídico se forme. Assim, continua o nobre jurista, não é possível chegar-se a outro entendimento senão o de que não há, na isenção, dispensa de pagamento da obrigação tributária, mas sim, incidência de norma pré-

28 MARTINS, Ives Gandra da Silva (coord.). Imunidades Tributárias: conferencista inaugural José Carlos Moreira Alves. São Paulo: Editora Revista dos Tribunais: Centro de Extensão Universitária, 1998. p. 32-33.

29 DERZI, Misabel Abreu Machado. Direito Tributário Brasileiro. Rio de Janeiro: Forense, 2000. p. 919.

30 COÊLHO, Sacha Calmon Navarro. Direito Tributário Contemporâneo. Misabel Abreu Machado Derzi, 2. ed. São Paulo : Editora Revista dos Tribunais, 2004. p. 353. 
excludente de juridicização. E finaliza dizendo que quem tem competência para tributar, também tem para conceder benefícios fiscais. ${ }^{31}$

No entendimento de Paulo de Barros de Carvalho, guardando a sua autonomia normativa, a regra de isenção investe contra um ou mais dos critérios da norma-padrão de incidência, mutilando-os, parcialmente. Releva ainda, ser obvio que não pode haver supressão total do critério, porquanto equivaleria a destruir a regra matriz, inutilizando-a como norma válida no sistema e enfatiza que o preceito de isenção subtrai parcela do campo de abrangência do critério do antecedente ou do consequente. ${ }^{32}$

\subsubsection{Não incidência}

Regina Helena Costa tem o entendimento de que a não incidência corresponde a inocorrência do impacto da norma jurídica sobre determinado fato, isto é, a indiferença de determinada conduta realizada, diante da norma jurídica. ${ }^{33}$

Sobre não incidência, José Souto Maior Borges, é enfático ao afirmar que o termo é usado comumente pela doutrina do Direito Tributário em sentido genérico, para abranger todos os casos de inexigibilidade de tributos e que pode ser empregada no sentido específico de inexistência de disposição prevendo o fato gerador. Critica ainda o fato de dar-se relevo ao conceito de não incidência que não é jurídico. E diz ainda que é evidente, portanto, que a expressão não incidência indica uma questão pré-jurídica que pode envolver duas situações:

a) ou não existe norma jurídica; b) ou o suporte fático não se concretizou suficientemente. ${ }^{34}$

\subsection{Evolução histórica da imunidade tributária dos templos de qualquer culto}

As imunidades - immunitas - remontam ao Império Romano, exoneravam algumas pessoas de serem tributadas, sendo que incluíam templos religiosos e bens públicos. Essas immunitas eram vistas como privilégios aos nobres e à igreja que não pagavam tributos, no

31 BORGES, J. S. M. Teoria geral da isenção tributária. 3. ed. São Paulo: Malheiros, 2007.

32 CARVALHO, Paulo de Barros. Curso de Direito Tributário. 21. ed. São Paulo: Saraiva, 2009, p. 528.

33 COSTA, Regina Helena. Imunidade Tributária. : Teoria e análise da jurisprudência do STF. Malheiros. 2006, p.39.

34 BORGES, José Souto Maior. Direito Tributário Moderno. São Paulo: Bushatsky, 1977. p. 36-37. 
entanto, os pobres eram tributados. ${ }^{35}$ Com a instauração do Estado independente, a Constituição de 1824, suprimiu a imunidade ao estabelecer "que ninguém está isento de contribuir para as despesas do Estado em proporção dos seus haveres". ${ }^{36}$ O Código Criminal do Império (1830), tipificava como crime policial a celebração em casa, ou edifício, que em sua forma externa parecesse um templo, ou publicamente, em qualquer lugar, o culto de outra religião que não professasse os dogmas da religião católica; a pena era de demolição da parte exterior do imóvel, combinada com multa, mantinha-se a congrua, remuneração dos padres. ${ }^{37}$

A Constituição de 1891, acabou com o monopólio da igreja católica, por intermédio de um decreto baixado por Deodoro da Fonseca e seus ministros, ${ }^{38}$ que previa a proibição de intervenção de autoridades em matérias religiosas, permitindo a plena liberdade de cultos, bem como autorizando que todas as igrejas e cultos pudessem adquirir e administrar seus bens, no entanto, sem privilégio especial. Essa constituição vedou que a União e as unidades federadas estabelecessem, subvencionassem ou embaraçassem a prática de cultos religiosos.

A grande novidade foi que nenhum culto poderia usufruir de subvenções oficiais ou que houvesse qualquer relação de dependência ou aliança com o Estado. ${ }^{39}$

Ressalta-se que as constituições de 1891, 1934 e 1937, não utilizavam a palavra templo, ${ }^{40}$ sendo que somente com a Constituição de 1946, a expressão voltou a ser usada, bem

35 CARNEIRO, Cláudio. Curso de Direito Financeiro e Tributário. 2. ed. Rio de Janeiro: Lumen Juris, 2010. V.1.

36 BRASIL. [Constituição (1824)]. Constituição do Império. Disponível em: http://www.planalto.gov.br/ccivil 03/constituicao/constituicao24.htm. Acesso em: 29 set. 2020.

37 BRASIL. Lei de 16 de Dezembro de 1830. Manda executar o Código Criminal. Disponível em: http://www.planalto.gov.br/ccivil_03/leis/lim/lim-16-121830.htm\#: :text=LEI\%20DE\%2016\%20DE\%20DEZEMBRO,Manda\%20executar\%20o\%20Codigo\%20Cr iminal.\&text $=1 \% \mathrm{C} 2 \% \mathrm{BA} \% 20 \mathrm{Toda} \% 20 \mathrm{a} \% 20 \mathrm{ac} \% \mathrm{C} 3 \% \mathrm{~A} 7 \% \mathrm{C} 3 \% \mathrm{~A} 3 \mathrm{o} \% 2 \mathrm{C} \% 20 \mathrm{ou}$, independentes $\% 20 \mathrm{da} \% 20 \mathrm{v}$ ontade\%20do\%20delinquente. Acesso em: 29 set. 2020.

38 BRASIL. Decreto $n^{\circ} 119-A$, de 7 de Janeiro de 1890. Prohibe a intervenção da autoridade federal e dos Estados federados em materia religiosa, consagra a plena liberdade de cultos, extingue o padroado e estabelece outras providencias. Disponível em: http://www.planalto.gov.br/ccivil 03/decreto/18511899/D119-A.htm. Acesso em: 29 set. 2020.

39 BRASIL. Constituição da República dos Estados Unidos do Brasil. art. 72, § 7º 1891. Disponível em: http://www.planalto.gov.br/ccivil_03/constituicao/constituicao91.htm. Acesso: 29 set. 2020.

40 MARTON, Ronaldo Lindimar José. A imunidade tributária dos templos de qualquer culto na interpretação da Constituição adotada pelo Supremo Tribunal Federal. 2013. Disponível em: http://www2.camara.leg.br/a-camara/documentos-e-pesquisa/estudos-e-notas-tecnicas/areas-daconle/tema20/CP13006_1.pdf. Acesso em: 29 set. 2020. 
como restabeleceu-se, nessa época, a imunidade tributária ${ }^{41}$ mantida com o advento da Constituição de 1988.

\section{TEMPLOS DE QUALQUER CULTO}

\subsection{Possível desvirtuamento da imunidade}

A Constituição Federal ${ }^{42}$ em seu art. 150, VI, $b, \S 4^{\circ}$, impõe à União, aos Estados e aos Municípios, limitações ao seu poder de tributar. Assim, sem prejuízo de outras garantias asseguradas ao contribuinte, é vedado a esses entes, instituir impostos sobre templos de qualquer culto, compreendendo somente o patrimônio, a renda e os serviços, relacionados com as atividades essenciais das entidades, no caso, templos de qualquer culto. Ainda, a Carta Magna orienta que nos termos do art. 146, caput, II, cabe à lei complementar regular as limitações ao poder de tributar. Segundo a doutrina, essa lei complementar é o Código Tributário Nacional - Lei 5.172/1966, art. $14 .^{43}$

Nesse contexto, não obstante presumir-se em favor do ente religioso a destinação do patrimônio, renda e serviços às suas atividades essenciais, e caber ao fisco comprovar eventual desvio de finalidade, é notória a ampla capacidade contributiva de diversas entidades religiosas que recebem vultosas quantias em ofertas, doações e dízimos. Realizam vendas de produtos religiosos, são proprietárias de vários patrimônios móveis e imóveis, urbanos e rurais, livrarias, editoras, lanchonetes, emissoras de TV, rádio, atuam em mídias sociais, auferem lucros de aplicações financeiras, enfim, atuam em diversos segmentos.

Pergunta-se: caso haja evidências robustas de desvio de finalidade das imunidades das atividades essenciais inerentes aos templos de qualquer culto, comprovadas pelo fisco, como por exemplo, confusão entre o patrimônio da instituição e dos dirigentes, estarão a doutrina e o Supremo Tribunal Federal - STF preparados para enfrentar o tema? E até que ponto a fé se transformou em um negócio rentável?

41 COSTA, Regina Helena. Imunidades Tributárias - Teoria e Análise da Jurisprudência do STF. São Paulo: Malheiros, 2001, p. 156.

42 BRASIL. [Constituição (1988)]. Constituição da República Federativa do Brasil. Disponível em: http://www.planalto.gov.br/ccivil_03/Constituicao/Constituicao.htm. Acesso em: 25 set. 2020.

43 BRASIL. Código Tributário Nacional. Disponível em: https://www2.senado.leg.br/bdsf/bitstream/handle/id/496301/000958177.pdf? sequence=1\&isAllowed=y. Acesso: 29 set. 2020. 
Esses são questionamentos que discutiremos nos próximos tópicos, tanto do ponto de vista doutrinário quanto da jurisprudência do STF.

\subsection{Doutrina e jurisprudência}

\subsubsection{Doutrina}

No que refere-se ao possível desvirtuamento da destinação da imunidade tributária, do ponto de vista doutrinário, entende Antonio Roque Carrazza, ${ }^{44}$ que a imunidade passa ao largo, quando demonstrada a existência, no culto, de finalidade primacialmente mercantil, isto é, de práticas típicas das entidades lucrativas, que provocam desequilíbrio concorrencial e pior - que levam ao enriquecimento pessoal dos membros da Igreja. No entanto, quando as igrejas recebem doações de bens e direitos escapam à incidência de do ITCMD. Essa posição não se altera quando a Igreja auxilia financeiramente (em moeda) outras congêneres, localizadas em países pobres ou com problemas de instabilidade econômica, para que lá sejam construídos locais de adoração, visando difundir ensinamentos religiosos, bem como realizar ajudas humanitárias. Reafirma que, no caso, a Igreja tem o direito de não reter o IRPJ-fonte sobre as doações em questão bastando, para isso, que cada remessa de dinheiro ao exterior seja devidamente documentada e esteja de acordo com as normas expedidas pelo Banco Central do Brasil. Destaca ainda que a Constituição Federal não exige que as doações feitas pela Igreja sejam aplicadas somente no território nacional, mas apenas que não tenham, inclusive no exterior, destinação comercial. As finalidades essenciais do culto podem perfeitamente ser alcançadas além das fronteiras do País. Entende ainda, que a única condição que o $\S 4^{\circ}$, do art. 150, da Constituição Federal impõe, para o gozo da desoneração fiscal é a ausência do ânimo de lucro, vale dizer, da intenção, da Igreja, de distribuir seus bens ou rendimentos aos que dirigem ou a terceiros que nela desempenham atividades laicas. Outros requisitos - entre os quais da territorialidade - não podem ser postos na legislação infraconstitucional, nem brotar de uma interpretação restritiva da Lei Maior. Diante disso, a imunidade em tela apenas desaparece se as doações da Igreja estiverem a serviço de finalidades estranhas ao seu culto, cabendo ao Poder Público o ônus da prova de tal desvirtuamento, o que só poderá ocorrer pelos meios em direito admitidos.

${ }^{44}$ CARRAZZA, Roque Antonio. Imunidades Tributárias dos templos e instituições religiosas. São Paulo: Noeses, 2015. 
No caso do imóvel rural, a Igreja regularmente constituída também goza de imunidade tributária, quando nele se desenvolvem atividades essenciais ao culto, como por exemplo, a formação de religiosos. A Situação não descaracteriza, ainda que ali presentes empreendimentos hortifrutigranjeiros ou agropastoris, desde que, no entanto, a produção se destine ao consumo interno, e se ao comércio, que os resultados obtidos venham totalmente reinvestidos na expansão do culto. Igualmente estão abrangidos pela imunidade em tela, os rendimentos obtidos pela Igreja em quermesse, contanto que, comprovadamente, revertam em benefício do culto. Essa ideia pode ser estendida aos serviços de comunicação radiofônica e televisiva, se realizados com intuito de evangelização. Destaca que o art. 14, do Código Tributário Nacional, não veda o exercício da atividade econômica pelas entidades que são imunes, o que não pode haver é a distribuição do lucro, sob pena de não gozar do benefício da imunidade. Salienta que a finalidade é o próprio fundamento da desoneração constitucional, pois é ela que vai determinar a correta aplicação das leis e dos atos administrativos que incidem sobre os templos de qualquer culto. ${ }^{45}$

Esse também é o entendimento de Regina Helena Costa que o templo não detém o patrimônio, a renda e serviços, mas a entidade religiosa. Dessa forma, a vinculação da imunidade se dá desde que haja relação com as atividades essenciais da Igreja. A autora entende como finalidades essenciais, as que são inerentes à própria natureza da entidade, são os propósitos que conduzem à sua instituição. Quanto às atividades ditas atípicas, entende que: se a entidade religiosa desenvolve atividades atípicas mas destina seus recursos à consecução de suas finalidades essenciais, goza de imunidade em relação a eles; ou se a entidade religiosa desenvolve atividades atípicas e não demonstra a destinação dos recursos assim obtidos à consecução de suas finalidades essenciais, não pode desfrutar da imunidade tributária com respeito àqueles. Seguindo nessa trilha, temos por irrelevante a natureza da fonte dos recursos da Igreja (aluguéis, prestação onerosa de serviços, aplicações financeiras, etc). Basta que seja lícita e não conspire contra o princípio da livre concorrência. ${ }^{46}$ No que se refere às rendas das entidades, Aires Fernandino Barreto entende que salvo se houver agressão ao princípio da livre concorrência, no mais podem as rendas ser provenientes de quaisquer fontes lícitas. Isto é até desejável juridicamente. Nada tem de repugnante. Pelo

45 CARRAZZA, Roque Antonio. Imunidades Tributárias dos templos e instituições religiosas. São Paulo: Noeses, 2015, p. 33.

46 COSTA, Regina Helena. Imunidades Tributárias - Teoria e Análise da Jurisprudência do STF. São Paulo: Malheiros, 2001, p. 159,160. 
contrário, a simples presença no texto constitucional da imunidade para essas entidades já mostra ser desígnio constitucional claro que elas obtenham rendas, empreguem seu patrimônio e desempenhem serviços tendo em vista esse objetivo, que, por sua vez, irá suportar e custear financeiramente aquelas finalidades realizadoras de valores constitucionalmente prestigiados, [...]. Se essas entidades têm imóveis, não se espera que eles fiquem ociosos. Se elas possuem terrenos, é altamente desejável que os explorem, direta ou indiretamente, com estacionamentos ou qualquer outra forma. Se são titulares de prédios, é bom que os aluguem, desde que fortaleçam suas finanças. Se têm maquinaria e pessoal especializado, que invistam em suas editoras ou que prestem serviços de ordem variada. Suas finalidades são constitucionalmente requeridas e só são realizáveis com recursos financeiros. Não existiriam se as entidades não alugassem, não prestassem serviços, não auferissem rendas. Seja em se tratando de templo, de partido político, de suas fundações, de instituição de educação ou de assistência social, o que a Constituição protege são os fins consistentes na liberdade do exercício religioso, na prestação de educação e no oferecimento de assistência social. O que a constituição veda é a distribuição de "lucros", diz o autor, melhor seria 'superávits'. ${ }^{47}$

Nas palavras de Aliomar Baleeiro, a imunidade aos templos de qualquer culto só produzirá todos os frutos almejados pela Constituição se for interpretada sem distinções sutis nem restrições mesquinhas. O culto não tem capacidade econômica. Não é fato econômico. $\mathrm{O}$ templo não deve ser só a igreja, sinagoga ou edifício principal, onde se celebra a cerimônia pública, mas também a dependência acaso contígua, o convento, os anexos por força de compreensão, inclusive a casa ou residência do pároco ou pastor, desde que não empregados em fins econômicos. Ainda, não repugna à Constituição inteligência que equipare ao templo imóvel - também a embarcação, o veículo, o vagão ou o avião usado como templo móvel, exclusivamente para a prática do culto. As "missões", em culto itinerante, podem utilizar, imunes de impostos, meios de transporte adaptados unicamente à finalidade do culto a que se propõem. $^{48}$

Percebe-se então que a doutrina pátria está alinhada ao fato de que é a destinação do patrimônio, bens e serviços das entidades religiosas que se configura como essencial para verificar se há ou não desvirtuamento das finalidades essenciais dos templos de

47 BARRETO, Aires Fernandino. Curso de Direito Tributário Municipal. São Paulo: Saraiva, 2009. p. 62-63. 48 BALEEIRO, Aliomar. Limitações constitucionais ao poder de tributar. Atualização de Misabel Abreu Machado Derzi. 7. ed. Rio de Janeiro : Forense, 2006. p. 503. 
qualquer culto. Observa-se então que a doutrina não vê nada de ilícito no fato de as instituições religiosas se tornarem um negócio rentável, desde que a destinação dos ganhos auferidos, nesses empreendimentos, retornem em favor do propósito da entidade e que não haja qualquer indício de afronta ao princípio da livre concorrência. Nesse sentido, atribuir à Administração Fazendária a possibilidade de impor sua versão, sem demonstrar que os fatos alegados ocorreram verdadeiramente, tipifica privilégio odioso totalmente inconstitucional, porque fere a posição de paridade que deve existir entre ela e o contribuinte, pela idêntica subordinação de ambos à lei tributária. Além de tudo, sendo negativa a prova a produzir, a inversão do onus probandi é impossível. ${ }^{49}$

\subsubsection{Jurisprudência}

Neste artigo, examinamos algumas decisões sobre como o Supremo Tribunal Federal - STF, enfrenta possíveis desvirtuamos da destinação da imunidade tributária relativa aos templos de qualquer culto. Consideramos, nessa pesquisa somente decisões colegiadas ocorridas no período compreendido entre 2012 e 2020. Vale destacar que após análise de diversas decisões, identificamos que a Suprema Corte julgou improcedentes vários pedidos sob o argumento de que o fisco deveria fazer prova de eventual desvio de destinação, e também porque nos termos da Súmula 279, STF, in verbis: para simples reexame de prova não cabe recurso extraordinário.

Importante ressaltar que foi identificado que o RE 562.351/RS, julgado em 04 set. 2012, foi a única decisão em que o conceito de religião foi discutido para saber se a maçonaria alcança a expressão 'templos de qualquer culto'. Ao final foi decido que a imunidade tributária conferida pelo art. $150, \mathrm{VI}, b$, é restrita aos templos de qualquer culto religioso, não se aplicando à maçonaria, em cujas lojas não se professa qualquer religião, portanto, foi negada a imunidade, o que até os dias de hoje é motivo de discussão na doutrina.

O modelo de julgamento colegiado adotado nos tribunais brasileiros, em termos simples, segue a técnica da contagem dos votos a partir de suas conclusões, ou seja, do resultado dispositivo da respectiva fundamentação. A decisão da corte se configura pela maioria dos resultados em determinado sentido, não importando se os fundamentos dos votos

49 CARRAZZA, Roque Antonio. Imunidades Tributárias dos templos e instituições religiosas. São Paulo: Noeses, 2015, p. 35. 
individuais dos magistrados forem divergentes entre $\mathrm{si}^{50}$. Essa técnica de julgamento termina por ocultar simbolicamente os conflitos internos, fornecendo ao público consumidor da prestação jurisdicional (e do texto, no campo da linguagem) a imagem de consenso, inclusive sobre os fundamentos da decisão.

Por conta desse ocultamento simbólico da divergência, nem sempre é fácil ao jurisdicionado identificar, nas decisões do STF (como de quaisquer tribunais brasileiros), as lacunas e falhas de fundamentação que, a rigor, implicariam a nulidade do ato jurisdicional. ${ }^{51}$

Assim chegamos à conclusão de que cabe à Administração Fazendária, fazer prova de que há desvio de destinação da imunidade dos templos de qualquer culto, pois caso contrário, não há que se falar em desvirtuamento da imunidade tributária, ainda que pese o fato de que parte das organizações religiosas tenham se tornado um negócio rentável.

Acórdãos analisados:

ARE 898896 AgR-EDv-AgR / RJ ${ }^{52}$

O tribunal não conheceu o RE sob o fundamento de que, em relação a determinado imóvel de entidade religiosa, a análise do preenchimento dos requisitos para a imunidade dependeria do revolvimento de fatos e provas.

50 RODRIGUEZ, José Rodrigo. Como decidem as cortes? Para uma análise comparativa entre as técnicas adotadas no Brasil e nos EUA. FGV: Rio de Janeiro: FGV, 2013. E-book.

51 ABREU, Rogério Roberto Gonçalves de; CAMPOS, Hélio Silvio Ourém; COLARES, Virgínia. A imunidade tributária dos templos e o conceito de religião no supremo tribunal federal. Revista Eletrônica do Curso de Direito da UFSM, Santa Maria, RS, v. 15, n. 2, e35079, maio./ago. 2020. ISSN 1981-3694. DOI: http //dx doi org/10.5902/1981369435079.

Disponível

em: https://periodicos.ufsm.br/revistadireito/article/view/35079. Acesso em: 30 set. 2020.

52 BRASIL. Supremo Tribunal Federal (1. Turma). ARE 898896 AgR-EDv-AgR / RJ. Rel: Min. Dias Toffoli, 24 de fevereiro de 2017. Disponível em: https://jurisprudencia.stf.jus.br/pages/search/sjur364606/false. Acesso em: 30 set. 2020 . 
ARE 900676 ED-AgR / ES 53

O tribunal não conheceu o RE sob o fundamento de que, em relação a determinado imóvel de entidade religiosa, a análise do preenchimento dos requisitos para a imunidade dependeria do revolvimento de fatos e provas.

\section{ARE $915011 \mathrm{AgR}^{54}$}

O tribunal reconheceu à entidade religiosa a imunidade tributária, como contribuinte de direito, em relação ao recolhimento de ICMS. Afirmou a presunção de destinação do patrimônio, da renda e dos serviços às finalidades essenciais das entidades imunes, cabendo ao fisco provar eventual desvio de finalidade.

\section{ARE $800395 \mathrm{AgR} / \mathrm{ES}^{55}$}

Ementa: agravo regimental em recurso extraordinário com agravo. Imunidade tributária de templos religiosos. Iptu. Imóvel vago. Desoneração reconhecida. O Supremo Tribunal Federal consolidou o entendimento de que não cabe à entidade religiosa demonstrar que utiliza o bem de acordo com suas finalidades institucionais. Ao contrário, compete à Administração tributária demonstrar a eventual tredestinação do bem gravado pela imunidade. Nos termos da jurisprudência da Corte, a imunidade tributária em questão alcança não somente imóveis alugados, mas também imóveis vagos. Agravo regimental a que se nega provimento.

O tribunal reafirmou a tese segundo a qual não cabe à entidade religiosa demonstrar a vinculação da destinação do bem imóvel de sua propriedade a suas finalidades essenciais,

53 BRASIL. Supremo Tribunal Federal (1. Turma). ARE 900676. ED-AgR / ES. Rel: Min. Luiz Fux, 23 de setembro de 2016. Disponível em: https://jurisprudencia.stf.jus.br/pages/search/sjur358716/false. Acesso em: 30 set. 2020.

54 BRASIL. Supremo Tribunal Federal (2. Turma). ARE 915011 AgR. Rel: Min.Celso de Mello, 10 de novembro de $2015 . \quad$ Disponível em: https://jurisprudencia.stf.jus.br/pages/search?base=acordaos\&pesquisa inteiro teor=false \&sinonimo=true $\& p$ $\underline{\text { lural }=\text { true } \& \text { radicais }=\text { false } \& \text { buscaExata }=\text { true } \& \text { page }=1 \& \text { pageSize }=10 \& q u e r y S t r i n g=915011 \& \text { sort }=\text { score } \& \text { sor }}$ tBy=desc. Acesso em: 30 set. 2020.

55 BRASIL. Supremo Tribunal Federal (1. Turma). ARE 800395 AgR / ES. Rel: Min. Roberto Barroso, 28 de dezembro de 2014. Disponível em: https://jurisprudencia.stf.jus.br/pages/search/sjur284702/false. Acesso em: 30 set.2020. 
mas, ao fisco, a tredestinação do bem. A decisão se referia a terrenos não edificados de entidade religiosa, os quais, segundo o tribunal, estariam compreendidos na imunidade.

RE $562351^{56}$

Ementa: I - O reconhecimento da imunidade tributária prevista no art. 150, VI, c, da Constituição Federal exige o cumprimento dos requisitos estabelecidos em lei. II - Assim, para se chegar-se à conclusão se o recorrente atende aos requisitos da lei para fazer jus à imunidade prevista neste dispositivo, necessário seria o reexame do conjunto fático-probatório constante dos autos. Incide, na espécie, o teor da Súmula 279 do STF. Precedentes. III - A imunidade tributária conferida pelo art. $150, \mathrm{VI}, \mathrm{b}$, é restrita aos templos de qualquer culto religioso, não se aplicando à maçonaria, em cujas lojas não se professa qualquer religião. IV Recurso extraordinário parcialmente conhecido, e desprovido na parte conhecida.

\section{ANÁLISE DOS PROJETOS DE LEI}

\subsection{PL}

Muito pertinente o posicionamento de José Eduardo Soares de Melo sobre como deve ser interpretada a cláusula "atendidos os requisitos da lei”, disposto no art. 150, VI, “c”, da Constituição Federal, pois nos ensina que o vocábulo lei não significa a edição de lei ordinária, reservada à normal competência outorgada aos poderes públicos; mas lei complementar, norma de estatura nacional, como autêntico produto do Estado total (global), que explicita a norma constitucional de eficácia limitada, e que, também inspira, fundamenta, e determina a edição de leis federais e estaduais, distritais e municipais (ordens parciais do Estado), como determina o art. 146, II, Constituição Federal. E continua sua explanação dizendo que a justificativa para considerar-se a exclusividade de lei complementar, para tratar da imunidade é facilmente perceptível, uma vez que, constituindo a competência (aptidão para as pessoas jurídicas de direito público instituírem tributos) matéria eminentemente constitucional, é lógico e natural que a exclusão de competência (como se configura a

56 BRASIL. Supremo Tribunal Federal (1. Turma). $\underline{R E ~ 562351}$. Rel: Min. Ricardo Lewandowski, 04 de setembro de $2012 . \quad$ Disponível em: https://jurisprudencia.stf.jus.br/pages/search?base=acordaos\&pesquisa_inteiro_teor=false \&sinonimo=true $\& p$ $\underline{\text { lural }=\text { true } \& \text { radicais }=\text { false } \& \text { buscaExata }=\text { true } \& \text { page }=1 \& \text { pageSize }=10 \& q u e r y \text { String }=562351 \& \text { sort }=\text { score } \& \text { sor }}$ $\underline{\mathrm{tBy}=\mathrm{desc}}$. Acesso em: 30 set.2020. 
imunidade) só pode ser veiculada por norma (lei complementar), que paire juridicamente acima de tais pessoas. ${ }^{57}$ No entanto, no entendimento de Hamilton Dias de Souza, a imunidade tributária possui norma autoaplicável, tornando-se, portanto, desnecessário que uma lei complementar estabeleça requisitos para a imunidade. ${ }^{58}$ Com a maxima venia ao autor, entendemos de modo diferente pela leitura mais atenta do disposto no art. 150, VI, "c"; art. 146, II, Constituição Federal ${ }^{59}$, combinada com a leitura do art. 14, caput, I, II, III, $\S 2^{\circ}$, CTN. ${ }^{60}$ Assim, entendemos que o art. 146, II, Constituição Federal, atribuiu competência para que o Código Tributário Nacional estabelecesse requisitos indispensáveis para que os destinatários das imunidades delas pudessem gozar, ficando, portanto, seus patrimônios, rendas e serviços imunes à incidência de impostos, desde que a destinação seja adequada às finalidades essenciais a que sem propõem. Entendemos dessa forma, não obstante o artigo tratar das imunidades dos destinatários da letra "c" do inciso VI do art. 150, Constituição Federal, uma vez que há uma necessidade de explicitação do que é imune a impostos, no caso dos templos de qualquer culto, sem com isso que se atribuam restrições à atividade religiosa, pois, como sabemos, a imunidade dos templos goza de presunção de legitimidade e de veracidade cabendo ao fisco provar o contrário. Nesse sentido o Tribunal Pleno do STF, ao deliberar acerca da cobrança de IPTU, de imóveis de titularidade de Mitra Diocesana alugados a terceiros, compreendeu no RE $325.822^{61}$, de relatoria do Ministro Ilmar Galvão, em acórdão redigido pelo Ministro Gilmar Mendes, haver paralelismo entre as imunidades do art. 150, VI "b" e "c", da Constituição da República, assim desde que revertidos os valores recebidos pela locação às finalidades essenciais da entidade religiosa, o numerário estaria livre de tributação.

Como vimos, muito embora o texto constitucional possa fixar os limites para a concessão das imunidades tributárias, por força do art. 146, II, Constituição Federal, cabe à lei complementar regulamentá-las. Nossa opinião é no sentido de que seria ideal termos uma lei

57 MARTINS, Ives Gandra da Silva (coord.). Imunidades Tributárias: conferencista inaugural José Carlos Moreira Alves. São Paulo: Editora Revista dos Tribunais: Centro de Extensão Universitária, 1998. p. 367 , $368,369$.

58 SOUZA, Hamilton dias de. Normas Gerais de direito tributário. São Paulo: Bushatsky, v.2, 1972.

59 BRASIL. [Constituição (1988)]. Constituição da República Federativa do Brasil. Disponível em: http://www.planalto.gov.br/ccivil_03/Constituicao/Constituicao.htm. Acesso em: 25 set. 2020.

60 BRASIL. Código Tributário Nacional. Disponível em: https://www2.senado.leg.br/bdsf/bitstream/handle/id/496301/000958177.pdf?sequence=1\&isAllowed=y. Acesso: 29 set. 2020.

61 BRASIL. Supremo Tribunal Federal (T. Pleno). RE 325822. Rel: Min. Ilmar Galvão, 18 de dezembro de 2002. Disponível em: https://jurisprudencia.stf.jus.br/pages/search/sjur96910/false. Acesso em: 30 set. 2020. 
complementar que pudesse melhor explicar quais são os requisitos do art. 14, I, II, III, CTN e sobre quais são os serviços exclusivos, mencionados no $\S 2^{\circ}$ do art. 14, CTN, diretamente relacionados com os objetivos institucionais das entidades de que trata este artigo, incluindo templos, previstos nos respectivos estatutos ou atos constitutivos, uma vez que são justamente esses serviços exclusivos que geram discussões doutrinárias e jurisprudenciais e que causam importante insegurança jurídica para os beneficiários da imunidade tributária sobre seus patrimônios, rendas e serviços, até porque acabam por ficar à mercê das diferentes interpretações das Fazendas Públicas Federal, Estaduais, Distrital e Municipais sobre o alcance dessas imunidades. Dessa forma, vale repetir as sábias palavras de Roque Antonio Carraza, que diz ser reservado à lei complementar, no caso, apenas o propósito de explicitação, afastando incertezas quanto ao alcance de tais desonerações, sendo que qualquer lei ordinária que venha a disciplinar o assunto terá, na melhor das hipóteses, caráter exclusivamente declaratório. Se repetir a Constituição e a lei complementar pertinente, será inócua; se as restringir, inconstitucional. Diz ainda, que quando muito, é dado à lei ordinária desde que não restrinja o alcance da imunidade - regular a constituição e funcionamento (limites formais) das entidades imunes; jamais fixar os parâmetros (limites objetivos) da própria imunidade, que, apontados na Carta Magna, somente podem ser regulamentados por meio de lei complementar e que tudo que for além de aspectos meramente estruturais das entidades imunes (normas meramente reguladoras de sua constituição e funcionamento), não é passível de regulação por lei ordinária que se está tolhida, nesses assuntos, por tão formidáveis peias, por muito maior razão, os decretos, as portarias, as instruções normativas, os comunicados, etc., que, dentro da pirâmide jurídica, ocupam posição a ela inferior. ${ }^{62}$

Diante do acima exposto, fomos em busca de projetos de lei, em âmbito federal, que pudessem apresentar novas propostas de enfrentamento do tema. Após buscas nos sítios da Câmara dos Deputados e do Senado Federal, identificamos as seguintes propostas de alterações na legislação pertinente às imunidades dos templos de qualquer culto, as quais passamos a comentar:

62 CARRAZZA, Roque Antonio. Imunidades Tributárias dos templos e instituições religiosas. São Paulo: Noeses, 2015. p. 166,167,168. 
PLP 21/20

Encontra-se em tramitação na Câmara dos Deputados o PLP 21/20 de autoria da Deputada Soraya Manato PSL/ES. O projeto dispõe sobre o patrimônio, a renda e os serviços relacionados às finalidades essenciais dos templos de qualquer culto religioso para gozo da imunidade tributária prevista no $\S 4^{\circ}$ do art. 150 da Constituição Federal. Segundo a deputada o objetivo é dar segurança jurídica a benefício já assegurado pela Constituição Federal. O Projeto de Lei Complementar (PLP) 21/20 determina que todas as atividades desenvolvidas por templo religioso estarão imunes de tributação sobre a renda, o patrimônio e os serviços, mesmo as lucrativas, desde que estejam relacionadas direta ou indiretamente às finalidades previstas no estatuto da organização. A proposta tramita na Câmara dos Deputados.

Ainda segundo o texto, para as atividades consideradas de extensão da atividade religiosa (por exemplo, exploração de cemitério ou de estacionamento ao lado do templo), a imunidade dependerá de regularidade dos encargos trabalhistas e previdenciários. O projeto encontra-se na Comissão de Finanças e Tributação e na Comissão de Constituição e Justiça e de Cidadania desde março/2020. ${ }^{63}$

Acreditamos ser esse um bom projeto de lei complementar pois busca justamente esclarecer quais são os patrimônios, rendas e serviços relacionados às finalidades dos templos de qualquer culto que gozam de imunidade.

\section{PEC 200/2016}

No Senado Federal ${ }^{64}$ encontra-se em tramitação a Proposta de Emenda à Constituição - PEC 200/2016, de autoria do Senador Marcelo Crivella PRB/RJ, que visa acrescentar o $§$ $1^{\circ}$-A ao art. 156 da Constituição Federal para prever a não incidência sobre templos de

63 BRASIL. Câmara dos Deputados. Projeto de Lei Complementar PLP 21/2020. Altera o disposto sobre o patrimônio, a renda e os serviços relacionados às finalidades essenciais dos templos de qualquer culto religioso para gozo da imunidade tributária prevista no $\S 4^{\circ}$ do art. 150 da Constituição Federal. Disponível em: https://www.camara.leg.br/propostas-legislativas/2238387. Acesso em: 31 set. 2020.

64 BRASIL. Senado Federal. Projeto de Emenda à Constituição - PEC 200/2016. Acrescenta o $\S 1^{\circ}$-A ao art. 156 da Constituição Federal para prever a não incidência sobre templos de qualquer culto do Imposto sobre a Propriedade Predial e Territorial Urbana (IPTU), ainda que as entidades abrangidas pela imunidade tributária sejam apenas locatárias do bem imóvel. Disponível em: https://www.camara.leg.br/proposicoesWeb/fichadetramitacao?idProposicao=2080470 . Acesso em: 31 set. 2020. 
qualquer culto do Imposto sobre a Propriedade Predial e Territorial Urbana (IPTU), ainda que as entidades abrangidas pela imunidade tributária sejam apenas locatárias do bem imóvel. Está pronta para Pauta do Plenário desde agosto de 2017.

Não acreditamos ser um bom projeto para discussão, pois tem pertinência limitada a tratar apenas do Imposto Predial e Territorial Urbano - IPTU, assunto já pacificado na jurisprudência dos tribunais superiores, pois deixa de lado, outros esclarecimentos de maior relevância sobre o tema, como por exemplo, a extensão e abrangência da imunidade dos templos de qualquer culto.

Não nos parece que o Congresso Nacional esteja disposto ou motivado a apreciar Projetos de Lei Complementar e Projetos de Emenda à Constituição sobre imunidades de templos de qualquer culto. Isso porque verifica-se que, por exemplo, a PEC 200 é do ano de 2016 e desde 2017 até os dias atuais encontra-se pronta para a Pauta do Plenário, o que ainda não ocorreu.

Diante das incertezas o que vemos é um cenário de insegurança jurídica por parte do contribuinte, causada pela escassez de ordenamento jurídico, diga-se Lei Complementar, que possa melhor explicitar os ditames constitucionais, em especial, que possam melhor esclarecer o que são os serviços exclusivos, diretamente relacionados com os objetivos institucionais das entidades de que trata o $\S 2^{\circ}$, art. 14, CTN. E assim, que possa afastar incertezas sobre o alcance das desonerações ocorridas pela imunidade concedida em âmbito constitucional, sem, portanto, restringir ou repetir o texto constitucional e a legislação complementar atual, e ainda, com o cuidado de não ser inconstitucional.

\subsection{O alcance da imunidade dos templos}

Como vimos ao longo desse estudo, as imunidades tributárias sobre os templos de qualquer culto têm respaldo no art. 150, VI "b", da Constituição Federal. Observamos que a doutrina não é unânime sobre o conceito e alcance da imunidade. Foram apontadas três teorias: a Teoria Clássica, que em termos gerais entende o alcance da imunidade limitado estritamente ao templo onde se celebra o culto, não se estendendo aos demais imóveis de propriedade da entidade religiosa. Por sua vez a Teoria Clássico-Liberal defende que todo o patrimônio da instituição religiosa, tudo que contribui para a realização da cerimônia religiosa, como a casa pastoral, as dependências contíguas e estacionamento, bem como veículos automotores, aeronaves, embarcações de navegação fluvial e marítima, enfim, todo o 
patrimônio que esteja afetado às suas finalidades essenciais. Os adeptos da Teoria Moderna, defendem que a imunidade se estende ao patrimônio, renda e aos serviços que estejam vinculados às finalidades essenciais do templo, dessa forma, o templo ganha conotação de organização ou associação. Vimos também que cabe à lei complementar o propósito da explicitação dos serviços exclusivos e essenciais prestados pelas organizações religiosas, sendo que atualmente, o art. 14 do CTN - Código Tributário Nacional tem balizado esse alcance. Discorremos também que além da Constituição Federal fixar os limites para a concessão das imunidades tributárias, por força do art. 146, II, cabe à lei complementar explicitar e regulamentar os limites para a concessão da imunidade. Entretanto, o CTN não atende perfeitamente aos critérios de explicitação, isso vem causando insegurança jurídica ao contribuinte, que depende da interpretação, muitas vezes divergente, da Fazenda Pública, seja federal, estadual, distrital ou municipal, o que acaba levando o contribuinte a recorrer no âmbito administrativo e judicial para que seja tutelado pelo Estado seu direito subjetivo. Assim, o tema imunidade tributária dos templos de qualquer culto carece de uma legislação que de fato esclareça o alcance dos serviços exclusivos que outorgam às entidades religiosas esse benefício.

Acompanhamos, portanto, o entendimento do professor Ives Gandra da Siva Martins, sem deixar de lado outros renomados doutrinadores que pensam da mesma forma, que, em suas sábias palavras nos ensina que o conceito e alcance da palavra templo é bastante amplo, ou seja, é "vivo", dessa forma, até mesmo os sacerdotes são imunes à tributação sobre suas "prebendas". As imunidades alcançam também a Contribuição sobre o Lucro Líquido CSLL, pois não se trata de isenção. Há vedação ou não ao poder de tributar? Não se pode falar em perdão fiscal, [...] isenção é renúncia fiscal; imunidade é proibição do fisco de tributar. Ninguém renuncia a um direito que não tem. Se o governo não tem o direito de tributar porque há vedação ao poder de tributar, por que vai dizer que há perdão? O Congresso Nacional é que tem o direito de representar, [...] o legislativo representa a totalidade da nação ${ }^{65}$. Daí a importância de uma norma que melhor explicite o que se entende por alcance da imunidade sobre os templos de qualquer culto. Se essa norma não for capaz de eliminar as divergências, que reduza a um nível aceitável para garantir a segurança jurídica do contribuinte.

65 MARTINS, Ives Gandra da Silva. Direito Tributário: entrevista. São Paulo: 10 set. 2020. 8 min. Disponível em: https://gandramartins.adv.br/video/entrevista-a-bandnews-10-09-2020/ . Acesso em: 30 set. 2020. 


\section{CONSIDERAÇÕES FINAIS}

Quando se iniciou o trabalho de pesquisa, constatou-se que havia dúvidas, tanto doutrinárias quanto jurisprudenciais sobre as hipóteses de incidência e alcance da imunidade tributária sobre templos de qualquer culto. Por essa razão, por tratar-se de matéria controvertida, decidimos por analisar o tema.

Diante disso, o artigo teve como objetivo geral identificar até que ponto a doutrina e a jurisprudência têm contribuído para verificar se há confusão entre o patrimônio, renda e serviços das instituições religiosas e de seus administradores.

Constata-se que o objetivo geral foi atendido porque o trabalho conseguiu demonstrar que a doutrina está alinhada no sentido de que é a destinação do patrimônio, renda e serviços dessas instituições religiosas que permite verificar se há ou não desvirtuamento de suas finalidades para a manutenção ou não da imunidade. No tocante à jurisprudência do Supremo Tribunal Federal - STF, percebemos que os diversos recursos que chegam até essa Corte Suprema, na maioria das vezes, não são conhecidos pelo simples fato de que a análise do preenchimento dos requisitos para a imunidade tributária das instituições religiosas dependem do revolvimento de fatos e provas, o que não é possível por força de entendimento já consolidado nessa Corte de que para o simples reexame de prova não cabe recurso extraordinário.

Dessa forma, percebe-se que tanto a doutrina quanto a jurisprudência do STF, têm o entendimento de que é a destinação dos requisitos fator preponderante para identificar se a instituição religiosa está aplicando seu patrimônio, renda e serviços em prol da entidade para fazer jus à imunidade. Ficou evidenciado que o entendimento doutrinário e jurisprudencial é uníssono no sentido de que a Administração Fazendária necessita fazer prova de que há desvio de destinação da imunidade, resguardado o devido processo legal, o contraditório e a ampla defesa, ainda que parte dessas instituições religiosas tenham se tornado um negócio rentável.

Os objetivos específicos foram atingidos na medida que foram abordados o conceito de imunidade tributária em sentido amplo, a imunidade tributária dos templos de qualquer culto. Abordamos também quais são os requisitos formais de constituição da entidade religiosa. Outro ponto importante que destacamos foi o relacionado aos requisitos para efetivação do direito à imunidade, onde percebemos que não basta simplesmente constituir um local para desenvolvimento das atividades consideradas imunes para que se pleiteie e exija 
os benefícios da imunidade. Abordamos também a distinção doutrinária entre imunidade, isenção e não incidência de tributos. Discorremos sobre a evolução histórica dos templos de qualquer culto desde o Império Romano até os dias atuais.

Analisamos também o possível desvirtuamento da imunidade dos templos de qualquer culto onde grande parte da doutrina entende que mesmo quando as entidades religiosas realizam atividades atípicas e destinam seus recursos às suas atividades religiosas, também gozam de imunidade e que o simples desígnio constitucional da imunidade, já demonstra que essas entidades necessitam obter rendas, patrimônios e prestar serviços para custearem suas atividades. Ficou também evidenciado pelos julgados do Supremo Tribunal Federal - STF, que possível desvirtuamento das atividades fins, só poderá ser suscitado mediante prova pré constituída pelas Fazendas Públicas, Federal, Estaduais, Distrital e Municipais, uma vez que as entidades gozam de liberdade religiosa concedida em âmbito constitucional. Ao Estado é proibido embaraçar sua prática.

Analisamos dois Projetos de Lei. O PLP 21/20 em tramitação na Câmara dos Deputados, de autoriza da Deputada Soraya Manato - PSL-ES, que propõe maior explicitação quanto ao patrimônio, renda e serviços relacionados às atividades essenciais dos templos visando maior segurança jurídica, uma vez que há carência de lei complementar nesse sentido. Determina, portanto, o Projeto de Lei da Deputada, que todas as atividades desenvolvidas por templos religiosos estarão imunes sobre a renda, o patrimônio e os serviços, mesmo as lucrativas, desde que relacionadas diretamente ou indiretamente às finalidades previstas no estatuto da organização. Projeto sem movimentação desde março de 2020.

Outro projeto analisado foi a Proposta de Emenda à Constituição - PEC 200/2016 de autoriza do Senador Marcelo Crivella - PRB-RJ, que visa acrescentar o $\S 1^{\circ}$-A ao art. 156 da Constituição Federal para prever a não incidência do Imposto Predial e Territorial Urbano IPTU - às entidades abrangidas pela imunidade ainda que sejam apenas locatárias do bem imóvel. O propósito dessa PEC - é também explicitar melhor o alcance das imunidades tributárias sobre os templos de qualquer culto. Essa PEC encontra-se sem movimentação desde agosto de 2017.

Percebemos que a lei complementar atual não é suficiente para esclarecer as várias dúvidas sobre a extensão e alcance das imunidades tributárias dos templos, prevista na Constituição Federal, o que traduz-se em urgente necessidade de que o Congresso Nacional 
mobilize-se nesse sentido para dar maior segurança jurídica aos contribuintes afetados pela imunidade.

Para a consecução dos resultados desse artigo, utilizamos a linha de pesquisa dogmática instrumental, sob o ponto de vista da Constituição Federal de 1988, de parte da doutrina nacional e da jurisprudência do Supremo Tribunal Federal - STF a partir de decisões colegiadas ocorridas no período entre 2012 e 2020. Consultamos sites da Câmara dos Deputados, do Senado Federal dentre outros, em busca de projetos de lei. Também foram consultados diversos artigos científicos, tudo isso, visando realizar uma contextualização teórico-prática através de embasamento científico da argumentação do artigo com elaboração de críticas e considerações em seções sequenciais relacionadas com os objetivos e a metodologia proposta.

A maior dificuldade que encontramos para a elaboração desse artigo foi identificar projetos de lei em âmbito federal, diga-se, de leis complementares que tenham por objetivo disciplinar o tema ainda bastante controvertido tanto na doutrina quanto na jurisprudência do STF. Somente encontramos os dois projetos citados anteriormente.

Destacamos que o presente artigo não teve a pretensão de esgotar o assunto. Assim, sugerimos que outros interessados em pesquisar o tema "imunidade dos templos de qualquer culto", que, para melhor entendimento, aprofundamento, direcionamento e qualidade de novas pesquisas, busquem realizar pesquisas e entrevistas junto aos operadores do direito, à líderes religiosos, parlamentares, magistrados, onde enfim, for possível melhor entender o tema, para que dessa forma a ciência possa ir se aproximando das verdades sobre as imunidades tributárias de templos de qualquer culto. 


\section{REFERÊNCIAS}

ABREU, Rogério Roberto Gonçalves de; CAMPOS, Hélio Silvio Ourém; COLARES, Virgínia. A imunidade tributária dos templos e o conceito de religião no supremo tribunal federal. Revista Eletrônica do Curso de Direito da UFSM, Santa Maria, RS, v. 15, n. 2, e35079, maio./ago. 2020. ISSN 1981-3694. DOI: http://dx.doi.org/10.5902/1981369435079. Disponível em: https://periodicos.ufsm.br/revistadireito/article/view/35079. Acesso em: 30 set. 2020.

BALEEIRO, Aliomar. Limitações constitucionais ao poder de tributar. 7. ed. Rio de Janeiro: Forense, 1998.

BARRETO, Aires Fernandino. Curso de Direito Tributário Municipal. São Paulo: Saraiva, 2009.

BORGES, J. S. M. Teoria geral da isenção tributária. 3. ed. São Paulo: Malheiros, 2007.

BORGES, José Souto Maior. Direito Tributário Moderno. São Paulo: Bushatsky, 1977.

BRASIL. [Constituição (1824)]. Constituição do Império. Disponível em: http://www.planalto.gov.br/ccivil_03/constituicao/constituicao24.htm. Acesso em: 29 set. 2020.

BRASIL. [Constituição (1988)]. Constituição da República Federativa do Brasil. Disponível em: http://www.planalto.gov.br/ccivil_03/Constituicao/Constituicao.htm. Acesso em: 25 set. 2020.

BRASIL. Câmara dos Deputados. Projeto de Lei Complementar PLP 21/2020. Altera o disposto sobre o patrimônio, a renda e os serviços relacionados às finalidades essenciais dos templos de qualquer culto religioso para gozo da imunidade tributária prevista no $\S 4^{\circ}$ do art. 150 da Constituição Federal. Disponível em: https://www.camara.leg.br/propostaslegislativas/2238387. Acesso em: 31 set. 2020.

BRASIL. Código Tributário Nacional. Disponível em: https://www2.senado.leg.br/bdsf/bitstream/handle/id/496301/000958177.pdf?sequence=1\&is Allowed=y. Acesso: 29 set. 2020.

BRASIL. Constituição da República dos Estados Unidos do Brasil. art. 72, § $7^{\circ} .1891$. Disponível em: http://www.planalto.gov.br/ccivil_03/constituicao/constituicao91.htm. Acesso: 29 set. 2020. 
BRASIL. Decreto $n^{\circ} 119-A$, de 7 de Janeiro de 1890. Prohibe a intervenção da autoridade federal e dos Estados federados em materia religiosa, consagra a plena liberdade de cultos, extingue o padroado e estabelece outras providencias. Disponível em: http://www.planalto.gov.br/ccivil_03/decreto/1851-1899/D119-A.htm. Acesso em: 29 set. 2020.

BRASIL. Lei de 16 de Dezembro de 1830. Manda executar o Código Criminal. Disponível em: $\quad$ http://www.planalto.gov.br/ccivil_03/leis/lim/lim-16-121830.htm\#: :text=LEI\%20DE\%2016\%20DE\%20DEZEMBRO,Manda\%20executar\%20o\%2 0Codigo\%20Criminal.\&text=1\%C2\%BA\%20Toda\%20a\%20ac\%C3\%A7\%C3\%A30\%2C $\% 2$ 0ou,independentes\%20da\%20vontade\%20do\%20delinquente. Acesso em: 29 set. 2020.

BRASIL. Senado Federal. Projeto de Emenda à Constituição - PEC 200/2016. Acrescenta o $\S 1^{\circ}$-A ao art. 156 da Constituição Federal para prever a não incidência sobre templos de qualquer culto do Imposto sobre a Propriedade Predial e Territorial Urbana (IPTU), ainda que as entidades abrangidas pela imunidade tributária sejam apenas locatárias do bem imóvel. Disponívelem:https://www.camara.leg.br/proposicoesWeb/fichadetramitacao?idProposicao=2 080470 . Acesso em: 31 set. 2020.

BRASIL. Supremo Tribunal Federal (1. Turma). ARE 800395 AgR / ES. Rel: Min. Roberto Barroso, 28 de dezembro de 2014. Disponível em: https://jurisprudencia.stf.jus.br/pages/search/sjur284702/false. Acesso em: 30 set.2020.

BRASIL. Supremo Tribunal Federal (1. Turma). ARE 898896 AgR-EDv-AgR/RJ. Rel: Min. Dias Toffoli, 24 de fevereiro de 2017. Disponível em: https://jurisprudencia.stf.jus.br/pages/search/sjur364606/false. Acesso em: 30 set. 2020.

BRASIL. Supremo Tribunal Federal (1. Turma). ARE 900676. ED-AgR / ES. Rel: Min. Luiz Fux, 23 de setembro de 2016. Disponível em: https://jurisprudencia.stf.jus.br/pages/search/sjur358716/false. Acesso em: 30 set. 2020.

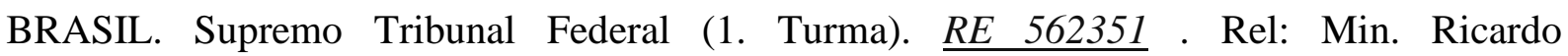
Lewandowski, 04 de setembro de 2012.Disponível em: https://jurisprudencia.stf.jus.br/pages/search?base=acordaos\&pesquisa_inteiro_teor=false \&sin onimo $=$ true $\&$ plural $=$ true $\&$ radicais $=$ false $\&$ buscaExata $=$ true $\&$ page $=1 \&$ pageSize $=10 \& q u e r y S t r$ ing $=562351 \&$ sort $=$ score $\&$ sortBy $=$ desc. . Acesso em: 30 set. 2020 .

BRASIL. Supremo Tribunal Federal (2. Turma). ARE 915011 AgR. Rel: Min.Celso de Mello, 10 de novembro de 2015. Disponível em: https://jurisprudencia.stf.jus.br/pages/search?base=acordaos\&pesquisa_inteiro teor=false \&sin onimo=true \&plural=true \&radicais=false \&buscaExata=true \&page $=1 \&$ pageSize $=10 \& q u e r y S t r$ ing $=915011 \&$ sort $=\_$score $\&$ sortBy=desc. . Acesso em: 30 set. 2020. 
BRASIL. Supremo Tribunal Federal (T.Pleno). RE 325822. Rel: Min. Ilmar Galvão, 18 de dezembro de $2002 . \quad$ Disponível em: https://jurisprudencia.stf.jus.br/pages/search/sjur96910/false.

CARNEIRO, Cláudio. Curso de Direito Financeiro e Tributário. 2. ed. Rio de Janeiro: Lumen Juris, v.1, 2010.

CARRAZZA, Roque Antonio. Curso de Direito Constitucional Tributário. 28. ed. São Paulo: Ed. Malheiros, 2012.

CARRAZZA, Roque Antonio. Imunidades Tributárias dos templos e instituições religiosas. São Paulo: Noeses, 2015.

CARVAlHO, Paulo de Barros. Curso de Direito Tributário. 21. ed. São Paulo: Saraiva, 2009.

COÊLHO, Sacha Calmon Navarro. Direito Tributário Contemporâneo. Misabel Abreu Machado Derzi, 2. ed. São Paulo: Editora Revista dos Tribunais, 2004.

COSTA, Regina Helena. Imunidades Tributárias: Teoria e Análise da Jurisprudência do STF. São Paulo: Malheiros, 2001.

DERZI, Misabel Abreu Machado. Direito Tributário Brasileiro. Rio de Janeiro: Forense, 2000.

HABLE, José. A imunidade tributária: os requisitos infraconstitucionais para o seu reconhecimento nas Instituições de Educação e de Assistência Social. In: PAES, José Eduardo Sabo; MAGALHÃES, Juliana Aparecida. (org.) Terceiro Setor e Tributação. São Paulo: Elevação, v. 8, 2016.

HABLE, José. Curso de processo administrativo fiscal: teoria e prática, com ênfase nas decisões dos Tribunais Administrativo de Recursos Fiscais. Rio de Janeiro: Lumen Juris, 2020.

LINS, Robson Maia. Curso de Direito Tributário Brasileiro. São Paulo: Noeses, 2019.

MARTINS, Ives Gandra da Silva (coord.). Imunidades Tributárias: conferencista inaugural José Carlos Moreira Alves. São Paulo: Editora Revista dos Tribunais: Centro de Extensão Universitária, 1998.MARTINS, Ives Gandra da Silva. Direito Tributário: entrevista. São Paulo: 10 set. 2020. 8 min. Disponível em: https://gandramartins.adv.br/video/entrevista-abandnews-10-09-2020/ . Acesso em: 30 set. 2020.

MARTON, Ronaldo Lindimar José. A imunidade tributária dos templos de qualquer culto na interpretação da Constituição adotada pelo Supremo Tribunal Federal. 2013. Disponível em: http://www2.camara.leg.br/a-camara/documentos-e-pesquisa/estudos-e-notas-tecnicas/areasda-conle/tema20/CP13006_1.pdf. Acesso em: 29 set. 2020. 
MENDES, Gilmar Ferreira; BRANCO, Paulo Gustavo Gonet. Curso de Direito Constitucional 6. ed. São Paulo: Saraiva, 2011.

RATIO ESSENDI. Razão de ser. Lex Magister. 2020. Disponível em: http://www.lex.com.br/Dicionarios.aspx?pagina=209. Acesso em: 27 set. 2020.

RODRIGUEZ, José Rodrigo. Como decidem as cortes? Para uma análise comparativa entre as técnicas adotadas no Brasil e nos EUA. FGV: Rio de Janeiro: FGV, E-book, 2013.

SOUZA, Hamilton dias de. Normas Gerais de direito tributário. São Paulo: Bushatsky,v.2.1972.

TORRES, Ricardo Lobo. Tratado de Direito Constitucional Financeiro e Tributário: Valores e princípios constitucionais tributários. Rio de Janeiro: Renovar, 2005.

VIEIRA, Thiago Rafael; REGINA, Jean Marques. Direito religioso: Questões Práticas. Porto Alegre: Concórdia, 2019. 